\title{
Landslide and slope stability evaluation in the historical town of Kruja, Albania
}

\author{
Y. Muceku and O. Korini \\ Faculty of Civil Engineering and Architecture, Epoka University, Tirana, Albania \\ Correspondence to: Y. Muceku (ymuceku@epoka.edu.al) \\ Received: 15 February 2013 - Published in Nat. Hazards Earth Syst. Sci. Discuss.: 13 July 2013 \\ Revised: 1 April 2013 - Accepted: 3 February 2014 - Published: 10 March 2014
}

\begin{abstract}
This paper describes landslides and slope stability evaluation in the urban area of Kruja, Albania. Kruja is a historical and heritage center, due to the existence of many important cultural monuments, including "Skanderbeg" castle and Bazaar square, etc. The urban area of Kruja has been affected by landslide effects, in the past and also the present. From this phenomenon many engineering objects such as buildings, roads, etc., are damaged and demolished. From engineering geological mapping at scale 1:5000 it is observed that many active landslides have dramatically increased in activity since the 1980s. The landslide types found in the studied area are earthslides, debris flow, as well as rockfall and rock rolling. Also, from field works and laboratory analysis, the slope stability of the whole urban area has been determined; for this purpose the studied zone is divided into stable and unstable areas, which helps to better understand mass movement activity as one of the most harmful hazards of geodynamic phenomena.
\end{abstract}

\section{Introduction}

The town of Kruja is located in the central part of Albania on one of the "Skanderbeg" mountain slopes. It represents one of the most famous heritage and historic centers in Albania. In this town mass movements have frequently occurred from which many engineering objects were damaged and/or demolished. That is why the Civil Geological Center of Tirana during the period 2004-2008 (Muceku, 2008) undertook engineering geological mappings at scale $1: 5000$ for which numerous boreholes were drilled, pits varying from $4.5-6.0 \mathrm{~m}$ to $10.0-12.0 \mathrm{~m}$, in order to take soil and rock samples for laboratory tests. Also, a detailed estimation of litho- logical, geomorphological, and hydrogeological geofactors was completed. Furthermore, from this work, the distribution, geometry and characteristics of landslides are determined and the slope stability of the urban area concerned is assessed.

\section{Geological setting}

On the basis of numerous geological studies (Meço and Aliaj, 2000; Xhomo et al., 2002; Muceku, 2008), the studied zone is built from Quaternary deposits, molasses rocks of Upper Miocene $\left(\mathrm{N}_{1}^{3}\right)$, flysch rocks of Lower Oligocene $\left(\mathrm{Pg}_{3}^{1}\right)$ and limestone rocks of Paleocene $\left(\mathrm{Pg}_{1}\right)$, Eocene $\left(\mathrm{Pg}_{2}\right)$ and $\mathrm{Up}$ per Cretaceous $\left(\mathrm{Cr}_{2}\right)$ (Fig. 1). The Quaternary deposits are represented by diluvial formations, which have occupied the major part of the studied area. They consist of silts and clays with fine sands, gravel-cobble mixture, as well as breccia rocks, varying in thickness from $1.0-3.0 \mathrm{~m}$ up to $5.0-8.0 \mathrm{~m}$. In the southeast of the area extend the molasses rocks that are composed of massive sandstones intercalated by siltstoneclaystone layers. They are transgressively situated on limestone rocks of Upper Cretaceous $\left(\mathrm{Cr}_{2}\right)$. As shown in Figs. 1 and 2, in the western part of the Kruja zone are spread out the layered limestone rocks of Upper Cretaceous $\left(\mathrm{Cr}_{2}\right)$, which are situated in the lower part of the studied geological profile. These rocks dip to east at an angle of $30-35^{\circ}$. Over these rocks lie with the stratigraphic break, the thin layered limestone rocks of Eocene $\left(\mathrm{Pg}_{2}\right)$ with the same dip angle of Upper Cretaceous limestone. In the central part of the Kruja zone extend flysch rocks of Oligocene $\left(\mathrm{Pg}_{3}^{1}\right)$, bounding on limestone rocks $\left(\mathrm{Pg}_{2}\right)$ with normal contact. In the eastern part on these rocks through intensive tectonic zone overthrust the limestone rocks $\left(\mathrm{Cr}_{2}, \mathrm{Pg}_{1}\right.$ and $\left.\mathrm{Pg}_{2}\right)$, which dip to east at an 


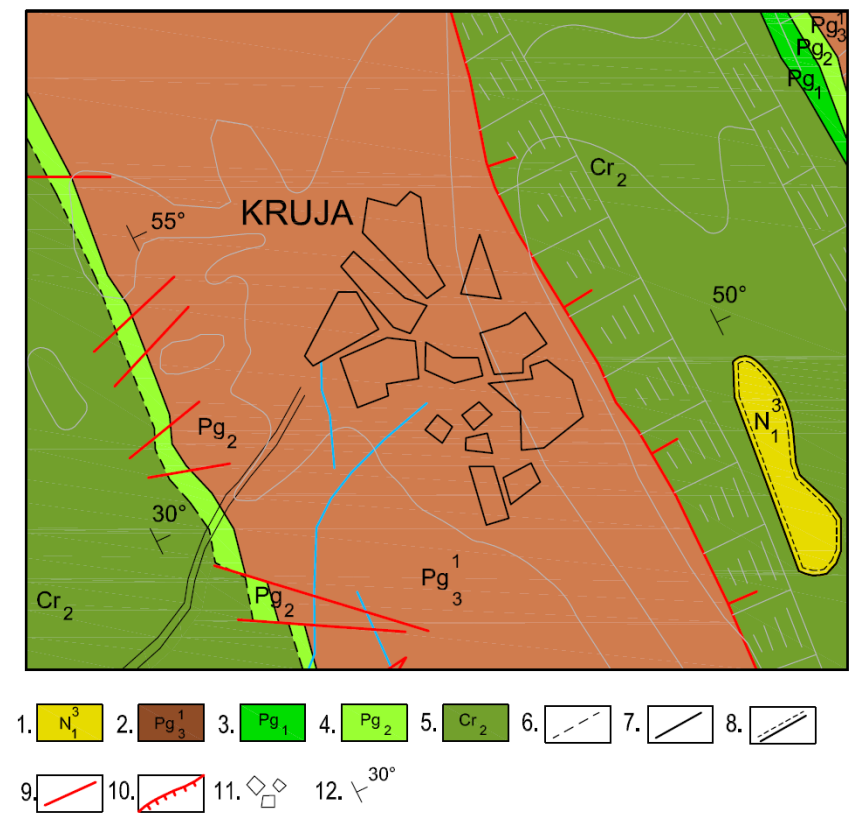

Fig. 1. Geological map of the Kruja region (Xhomo et al., 2002). (1) molasses rocks of Upper Miocene $\left(\mathrm{N}_{1}^{3}\right)$ sandstones and claystones, (2) flysch rocks of Lower Oligocene $\left(\mathrm{Pg}_{3}^{1}\right)$ interbed of siltstonesclaystones with sandstones, $(3,4,5)$ limestone rocks of the Paleocene $\left(\mathrm{Pg}_{1}\right)$, Eocene $\left(\mathrm{Pg}_{2}\right)$ and Upper Cretaceous $\left(\mathrm{Cr}_{2}\right)$, (6) stratigraphic break boundary, (7) normal boundary, (8) transgressive boundary, (9) tectonics line, (10) overthrust tectonics, (11) Kruja, (12) bedding with amount of dip.

angle of $50^{\circ}$. The flysch rocks are thin siltstone-claystone layers with thin sandstone intercalations. In relation to geological structure these rocks build an overturned syncline (Xhomo et al., 2002; Meço and Aliaj, 2000; Muceku, 2008), with limbs dipping $45-55^{\circ}$ to the east (Fig. 2). It could be emphasized that the rocks mentioned above in the upper part of lithological profile are affected by weathering crust formation processes, which happened non-uniformly over the whole area.

\section{Geomorphological characteristics}

From a geomorphological point of view, the urban area of Kruja represents a hilly slope consisting of limestone, breccia and flysch rocks with inclination angles ranging from 16$25^{\circ}$ up to $30-40^{\circ}$. One of the slopes' characteristic features is the concavo-convex profile, which is formed as a result of the torrent operation and geodynamic phenomena occurrences such as landslides and erosions. During rainfall, a considerable mass of debris and rock fragments flows down the slope through these drains and accumulates on the middle and lower levels of hilly zones. In some places of the studied area, the slope angle exceeds the angle of repose of the accumulated materials, and then the hill slope mass materials

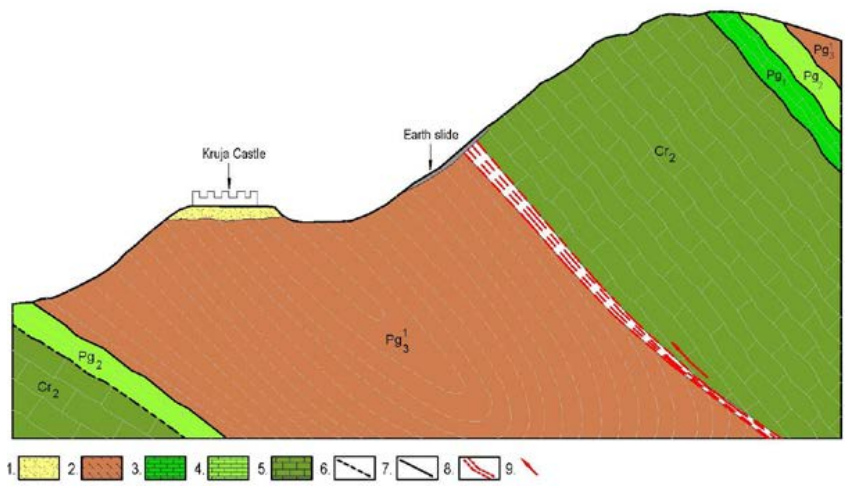

Fig. 2. Geological profile of the Kruja region (Xhomo et al., 2002). (1) breccia rocks of Quaternary $(Q)$, (2) flysch rocks of Lower Oligocene $\left(\mathrm{Pg}_{3}^{1}\right),(3,4,5)$ limestone rocks of Paleocene $\left(\mathrm{Pg}_{1}\right)$, Eocene $\left(\mathrm{Pg}_{2}\right)$ and Upper Cretaceous $\left(\mathrm{Cr}_{2}\right)$, (6) stratigraphic break boundary, (7) normal boundary, (8) overthrust tectonics, (9) mass movement direction.

lie in limit state conditions ready to move down. The failed slopes are generally devoid of any vegetation, while the surrounding area is moderately covered with pine trees. From our investigations several failures are mapped. They occurred in the upper and central parts of the urban area and played a main role in the modeling of the terrain, forming a lot of escalations. These failures mostly trend from the northwest to the southeast and dip towards the hill slope.

\section{Mass movements}

The mass movement activity is related to various factors, which triggered this phenomenon in the studied area. The main factors that initiated and favored this phenomenon are lithology (soils and rocks), morphology (slope inclination and slope shape), the tectonic movement zone, earthquake events, rainfall and man-made works.

Several geotechnical investigations carried out in the Kruja urban area concluded that it is subject to landslides. According to Cruden and Varnes (1996), they are earthslide, debris flows and rock rolling types.

\subsection{Earthslide}

In the central and southeastern parts of Kruja have occurred two earthslides. The larger one was $500.0-550.0 \mathrm{~m}$ long, 200.0-320.0 m wide and 4.0-8.5 m thick (Figs. 3 and 5). It occurred in 1990. During heavy rain periods some sites in the upper part of the landslide move slowly downwards on hill slopes. Over this slide are built the Kasmaj, Perlataj and Berberaj squares of Kruja, where about 12, 2-3 storey buildings were demolished and about 47 others affected by joint failure and cracks. This certainly constitutes a serious threat to human life for the people who live in this area. Besides, this mass movement has affected transportation corridors and 


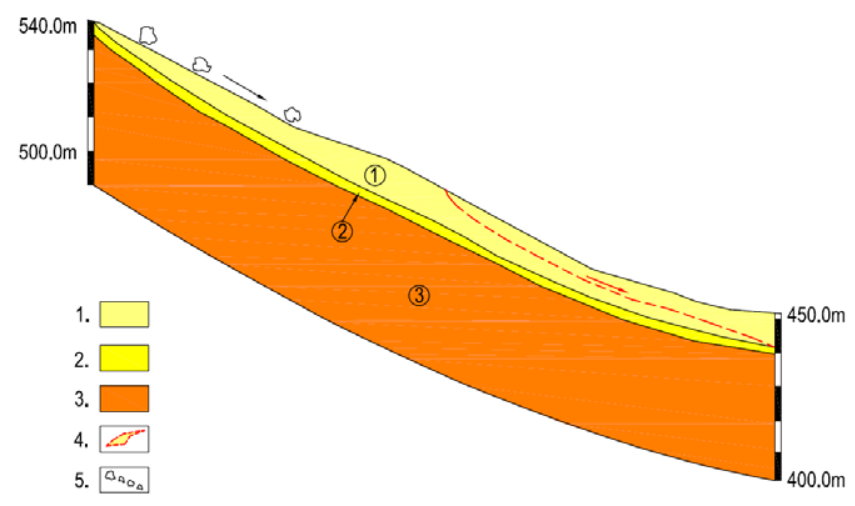

Fig. 3. Lithological profile of engineering geology site no. $\mathrm{II}_{1}$. (1) inorganic silts and clays with fine sands, (2) weathering crust of flysch rocks, (3) flysch rocks, (4) earthslide body, (5) breccia and limestone blocks.

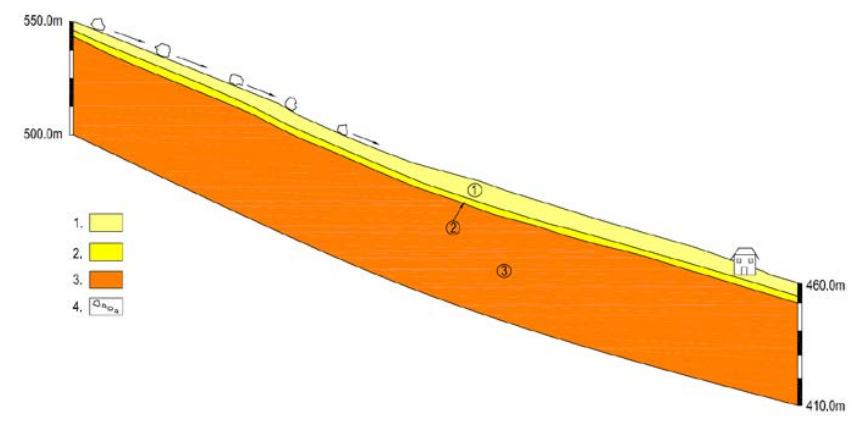

Fig. 4. Lithological profile of engineering geology site no. $\mathrm{II}_{3}$. (1) inorganic silts and clays with fine sands, (2) weathering crust of flysch rocks, (3) flysch rocks, (4) breccia and limestone blocks.

communication facilities. The upper part of the landslide body crown is situated directly in the tectonic fractured zone (Figs. 2 and 7), which is one of the main factors favoring this phenomenon (Muceku, 2008 and 2009), whereas the medium and lower part of the slide plane is situated on a weathering crust of flysch rocks, which is 1.4-2.2 m thick (Figs. 3, 4 and 5). The slide's body consists of silts and clays with fine sands. The other (smaller) earthslide is $220.0 \mathrm{~m}$ long, $120.0 \mathrm{~m}$ wide and $2.8-5.5 \mathrm{~m}$ thick (Fig. 7). On this slide a traffic road and green park are built, which are often damaged from its moving. Several geo-factors favor this mass movement. They are the soft rock flysch, which is intensively disturbed by tectonic activity, as well as rainfall and underground waters. The tectonic zone works as a collector of the karstic water of limestone rocks of "Skanderbeg" mountain. These waters flow out in the form of spring water at the point of contact of soil and flysch rocks on the landslide's crown, influencing the lowering of geotechnical properties of the soils and rocks. Furthermore, this area is very much affected by rainfall averaging $1800-2000 \mathrm{~mm} \mathrm{yr}^{-1}$ (Themelko and Mustaqi, 1996). The rainfall reached its climaxes in $1959(3160.6 \mathrm{~mm})$ and

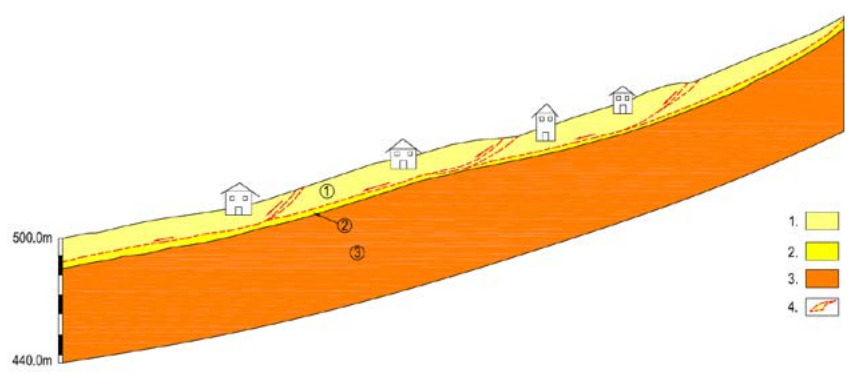

Fig. 5. Lithological profile of engineering geology site no. $\mathrm{II}_{4}$. (1) inorganic silts and clays with fine sands, (2) weathering crust of flysch rocks, (3) flysch rocks, (4) earthslide body.

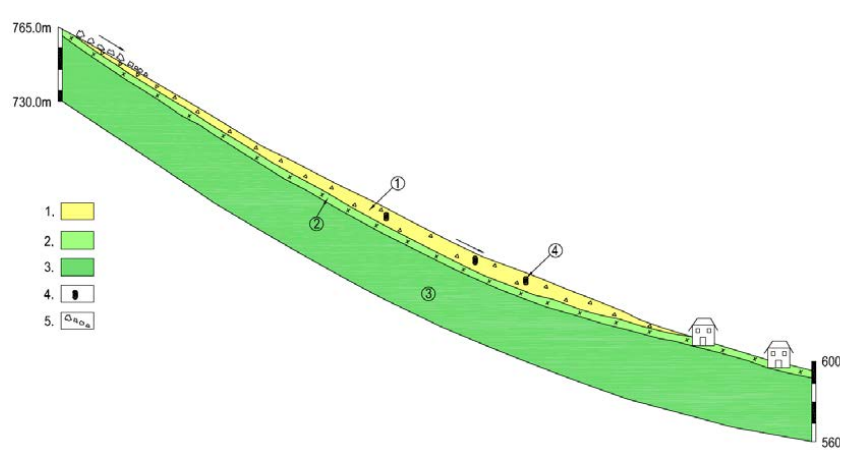

Fig. 6. Lithological profile of engineering geology site no. $I_{1}$. (1) gravel-cobble mixture with no fines, (2) weathering crust of limestone, medium strong rocks, (3) strong limestone rocks, (4) barrierstone masonry wall, (5) limestone blocks.

1960 (3569.9 mm) (Naçi, 1974). Man-made works (foundation excavation) have also affected earthslide occurrences. Also, the morphology of the steep slopes in this area can also increase susceptibility to landslide events. Based on geotechnical investigations (Muceku, 2008) engineering measures are taken in the upper part of large landslide occurrences, including pile-based applications, for the protection of roads and 47 buildings at risk that are part of old Albanian culture.

\subsection{Debris flows}

As mentioned above, the studied area represents a mountain zone where slope inclinations vary from $16^{\circ}$ up to $40^{\circ}$. In the east of this zone extends "Skanderbeg" mountain with very steep slope inclination varying from $32-55^{\circ}$ up to $85^{\circ}$ (Figs. 6 and 7). From weathering processes of limestone, as well as rainfall water erosion and transportation on these slopes, are accumulated the unconsolidated materials (gravel-cobble mixture with no fines). The debris materials are detached from the upper parts of limestone rocks of "Skanderbeg" mountain and are accumulated in the medium to lower parts of its slope. Rock debris comes to rest in the run out zone, which includes gentler slopes where boulders and blocks roll or bounce beyond the base of the acceleration 


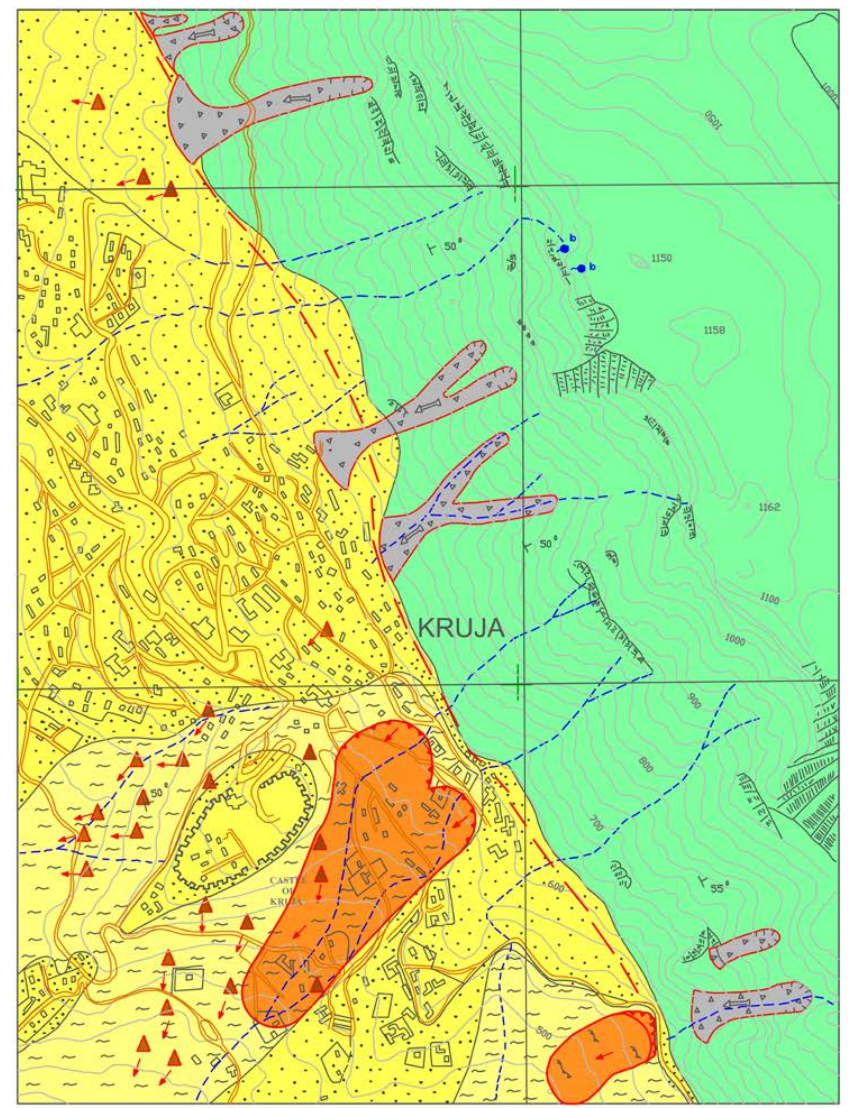

1.
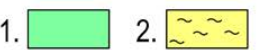

3.

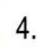

4.

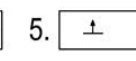

6.

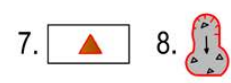

9.

10. $-\cdots$

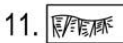

12. $\cdots$

13. -100

14.

15. एव

16. $\approx$

Fig. 7. Engineering geological map of Kruja, scale 1:5000 (Muceku, 2008). (1) Limestone rocks, (2) flysch rocks, (3) breccia rocks, (4) lithological boundary, (5) strata dip angle, (6) slide direction, (7) rock blocks, (8) debris flows, (9) earthslides, (10) tectonic line, (11) limestone cliff, (12) streams, (13) altitude line, (14) water spring, (15) buildings, (16) traffic road.

zone. They are deposited in ephemeral streams and are ready to move down in the form of debris flows (Fig. 6) that are open-sloped (Dahl et al., 2010). The debris flows have this dimension range: $120.0-250.0 \mathrm{~m}$ up to $350.0-400.0 \mathrm{~m}$ long, $50.0-100.0 \mathrm{~m}$ wide and $1.8-3.5 \mathrm{~m}$ up to $5.5-7.0 \mathrm{~m}$. Two of these zones are located over Kruja. The volume of debris accumulated in these cones is $28000 \mathrm{~m}^{3}$ and $12000 \mathrm{~m}^{3}$, respectively, constituting a present risk for this part of town. The debris flow phenomena in this area have occurred several times in previous years, such as the debris flows of 2004 and 2010 that damaged several buildings, green landscape in the eastern part of Kruja and also adjacent traffic roads. Barrier-stone masonry walls were built for protection against debris flows

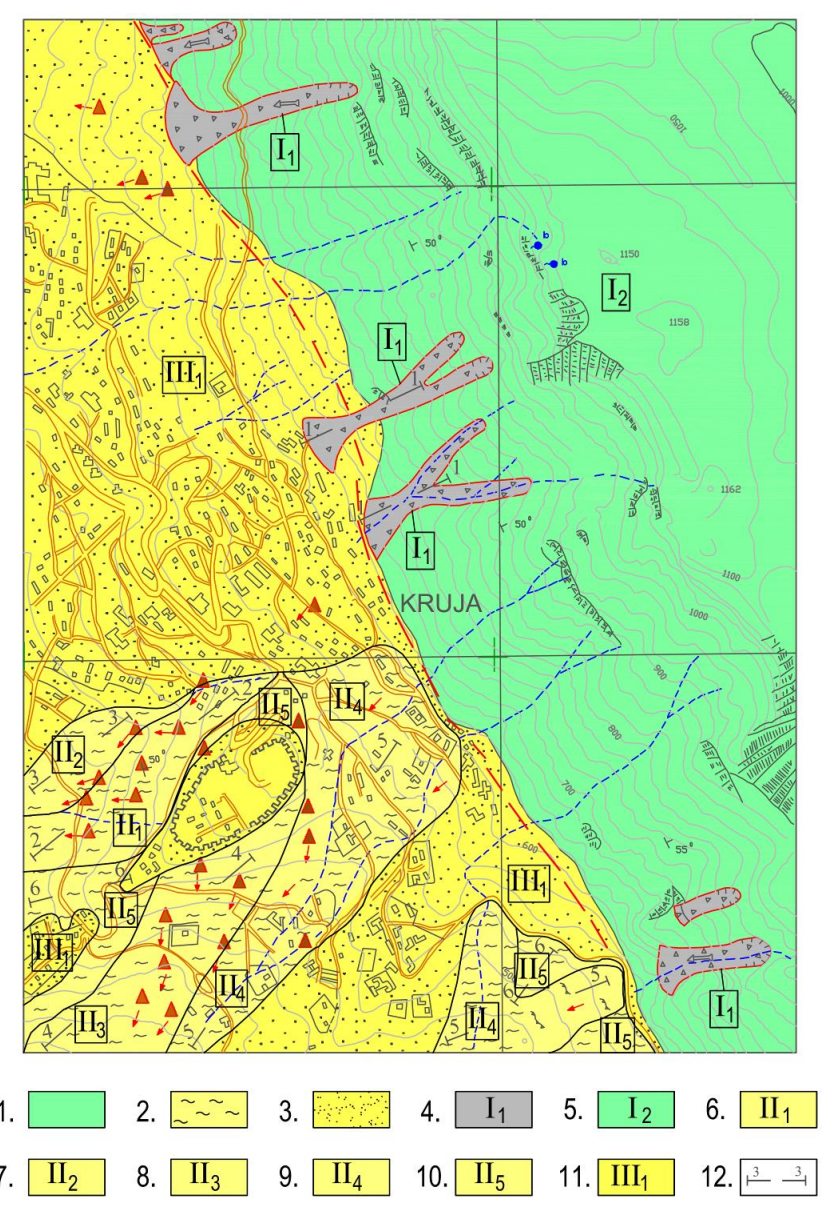

Fig. 8. Engineering geological zoning map of Kruja, scale $1: 5000$. (1) Engineering geology zone with basement built of limestone rocks, (2) engineering geology zone with basement built of flysch rocks, (3) engineering geology zone with basement built of breccia rocks, $(4,5,6,7,8,9,10,11)$ engineering geological sites, (12) profile trace.

in the lower part of colluvium cones. These protections have reduced only the potential damages from this phenomenon without averting the debris flow in this area. Furthermore, since Kruja is built on the down slopes of "Skanderbeg" mountain with inclination angle $14-27^{\circ}$, with an unconsolidated debris source above town, ready to move down, this means that a high risk is present.

\subsection{Rock rolling}

Rock toppling, falls and rolling phenomena have occurred in the middle-upper part of the "Skanderbeg" mountain slope. The blocks and stones are composed of limestone and breccia rocks of different sizes with irregular shapes. As seen in Figs. 4, 6 and 7 twenty-three breccia and limestone blocks $\left(3.2-4.5 \mathrm{~m}^{3}\right.$ up to $\left.12.0-20.0 \mathrm{~m}^{3}\right)$ have moved downwards and stopped on the hill slopes of the urban area, with an 
Table 1. Physical properties of soils and rocks.

\begin{tabular}{|c|c|c|c|c|c|c|}
\hline \multirow[b]{2}{*}{ Site } & \multirow[b]{2}{*}{$\begin{array}{l}\text { Geotech. } \\
\text { layers }\end{array}$} & \multicolumn{5}{|c|}{ Properties } \\
\hline & & $\begin{array}{l}\mathrm{LL} \\
(\%)\end{array}$ & $\begin{array}{l}\text { PL } \\
(\%)\end{array}$ & $\begin{array}{l}\mathrm{Wn} \\
(\%)\end{array}$ & $\begin{array}{r}\gamma \\
\left(\mathrm{kN} \mathrm{m}^{-3}\right)\end{array}$ & $\left(\mathrm{kN} \mathrm{m}^{-3}\right)^{\gamma_{\mathrm{o}}}$ \\
\hline \multirow{3}{*}{$\mathrm{I}_{1}$} & no. 1 & - & - & 5.0 & 19.0 & 26.14 \\
\hline & no. 2 & - & - & 0.41 & 27.1 & 28.9 \\
\hline & no. 3 & - & - & 0.02 & 26.9 & 28.8 \\
\hline \multirow{3}{*}{$\mathrm{II}_{1}$} & no. 4 & 29.5 & 20.2 & 23.7 & 19.0 & 26.86 \\
\hline & no. 5 & - & - & 7.3 & 21.8 & 25.60 \\
\hline & no. 6 & - & - & 3.20 & 25.3 & 25.5 \\
\hline $\mathrm{II}_{2}$ & no. 7 & 34.1 & 23.8 & 21.6 & 19.8 & 26.94 \\
\hline $\mathrm{II}_{3}$ & no. 8 & 32.4 & 22.8 & 24.53 & 19.6 & 27.1 \\
\hline $\mathrm{II}_{4}$ & no. 9 & 29.8 & 24.0 & 21.0 & 19.8 & 27.0 \\
\hline $\mathrm{II}_{5}$ & no. 10 & 29.0 & 19.8 & 21.6 & 19.5 & 26.9 \\
\hline
\end{tabular}

$\mathrm{LL}-$ liquid limit, $\mathrm{PL}-$ plastic limit, $\mathrm{Wn}-$ natural water, $\gamma-$ density, $\gamma_{\mathrm{o}}-$ specific density.

inclination angle of $16-27^{\circ}$. They are situated on the urban area slope with an inclination angle of $16-27^{\circ}$. Most of them rest in unstable state conditions that occur often times due to landslide and erosion activities (Figs. 19 and 20). From this process some large blocks during heavy rain events do roll down, damaging roads, green landscape and buildings. So, this phenomenon is a real risk to life and engineering objects such as buildings, roads, etc. (Figs. 19 and 20).

\section{Geotechnical conditions}

The studied area represents one of the main towns in Albania due to its historical and cultural heritage, not to mention its touristic potential. Because of this it was necessary to conduct the engineering geological investigations related to the slope stability of this area. These investigations included the engineering geological mapping at scale 1:5000, and drillings and pit works executed on the landslide body and also throughout hill slopes over urban areas. Therefore on the two earthslide bodies, 13 boreholes were drilled, including 37 more drilled on the slopes where urban areas are located; the depth range was from 8.0 to $12.0 \mathrm{~m}$ and 42 other pits (4.5$5.5 \mathrm{~m}$ ). From these works were taken 63 undisturbed and 16 disturbed samples of soils and rocks for laboratory testing, which were analyzed for physical and mechanical properties such as grain size distribution, atteberg limits (LL, PL), density $(\gamma)$, specific density $\left(\gamma_{\mathrm{o}}\right)$, internal friction angle $(\varphi)$, cohesion (c) and $\sigma$-uniaxial compressive strength of rocks. It is important to emphasize that 17 soil samples were analyzed in a triaxial test $(U, U)$. These results are briefly discussed here and given in tables 1 and 2. Based on geofactor criteria such as lithology and geotechnical properties the urban area is classified into several engineering geology zones. From lithology features there are three types of rocks, which are limestone, flysch, and breccia. Related to geotechnical properties, the limestone, breccia and flysch rocks, respectively, are included in hard, weak and very weak rock classes
Table 2. Mechanical properties of soils and rocks.

\begin{tabular}{llrrrrr}
\hline & & \multicolumn{5}{c}{ Properties } \\
\cline { 3 - 7 } Site & $\begin{array}{l}\text { Geotech. } \\
\text { layers }\end{array}$ & $\begin{array}{r}\phi \\
\left({ }^{o}\right)\end{array}$ & $\begin{array}{r}\mathrm{c} \\
(\mathrm{kPa})\end{array}$ & $\begin{array}{r}\mathrm{E} \\
(\mathrm{Mpa})\end{array}$ & $v$ & $\begin{array}{r}\text { Soils \& } \\
\text { rocks }\end{array}$ \\
\hline & no. 1 & 39 & 0.0 & 27.0 & 0.32 & $\mathrm{GP}$ \\
$\mathrm{I}_{1}$ & no. 2 & 54 & 1324 & 17888 & 0.21 & $\mathrm{~L}$ \\
& no. 3 & 56 & 9586 & 104001 & 0.19 & $\mathrm{~L}$ \\
& no. 4 & 18 & 22 & 7.55 & 0.33 & $\mathrm{CL}$ \\
$\mathrm{II}_{1}$ & no. 5 & 28 & 94 & 146.6 & 0.25 & FL \\
& no. 6 & 36 & 189 & 1300 & 0.22 & FL \\
$\mathrm{II}_{2}$ & no. 7 & 18 & 28 & 29.55 & 0.29 & ML \\
$\mathrm{II}_{3}$ & no. 8 & 17 & 25 & 12.24 & 0.31 & $\mathrm{CL}$ \\
$\mathrm{II}_{4}$ & no. 9 & 19 & 30 & 35.25 & 0.28 & $\mathrm{CL}$ \\
$\mathrm{II}_{5}$ & no. 10 & 18 & 28 & 21.57 & 0.22 & $\mathrm{CL}$ \\
\hline
\end{tabular}

$\varphi$ internal friction angle, c cohesion, E elastics module, $v$ Poisson ratio, GP, CL, ML soils group, L limestone rocks, FL flysch rocks.

(Romana, 1996). So, from these features the urban area has been classified into engineering geology zones built from a basement of limestone, breccia and flysch rocks. Moreover, based on the terrain's morphology (slope inclination angle), soil thickness and physical mechanical properties of soils situated over bedrocks, each engineering geology zone was divided into several engineering geology sites (Fig. 8), which represent the homogeneous areas. In this paper we treat the geotechnical conditions of unstable areas. These areas are normally found on hill slopes built by soils represented by inorganic clays and silts with sand content and gravel-cobble mixture with no fines, which are situated, respectively, on flysch and limestone slopes with an inclination angle ranging from $15-25^{\circ}$ up to $28-35^{\circ}$. On the other hand, the stable slopes (the northern part of the urban area) are not discussed here, due to the fact that they are built by consolidated breccia rocks with a high safety factor.

The geotechnical conditions of soils and rocks found in the studied area are analyzed according to engineering geology zones and sites. The studied area for the purposes set forth in this study is itemized as below.

a. The engineering geology zone no. I, with a basement built of limestone rocks (Fig. 8). This zone extends to the eastern part of Kruja on a mountain slope. Based on lithology characteristics and physical-mechanical properties of soils and rocks, this zone was classified into two engineering geology sites, nos. $\mathrm{I}_{1}$ and $\mathrm{I}_{2}$. The engineering geology sites nos. $\mathrm{I}_{1}$ and $\mathrm{I}_{2}$, respectively, are composed of diluvial soils and limestone rocks (Fig. 6). The engineering geology site no. $\mathrm{I}_{1}$ is built of three geotechnical layers, which are:

The geotechnical layer no. $I$ is represented by a gravel-cobble mixture with no fines.

The geotechnical layer no. 2 is a weathering crust of limestone rocks. 
The geotechnical layer no. 3 is limestone rocks.

The first geotechnical layer is situated on limestone slopes of "Skenderbeg" mountain with an inclination angle of $23-34^{\circ}$. It originated from the upper part of the mountain slopes as a result of rockfall phenomena. In relation to the Unified Soils Classification System (Samtani and Nowatzki, 2006), these soils are included in the GP group and characterized by low geotechnical parameters (tables 1,2). The second geotechnical layer constitutes the weathering crust of limestone rocks, which lies in the upper part of the lithological profile. It is fractured, creating many limestone blocks ready to detach and roll down. This geotechnical layer is $1.5-2.5 \mathrm{~m}$ thick and in relation to geotechnical properties (tables 1,2) is involved in medium strong rocks (Romana, 1996). The third geotechnical layer is composed of limestone rocks $(L)$, which are hard rock (Romana, 1996). In the case of engineering geology site no. $I_{2}$ only the second and third layers are observed, as explained above.

b. The engineering geology zone no. II, with a basement built of flysch rocks (Fig. 8). From field work and laboratory testing in this zone, five engineering geology sites are distinguished (nos. $\mathrm{II}_{1}, \mathrm{II}_{2}, \mathrm{II}_{3}, \mathrm{II}_{4}$ and $\mathrm{II}_{5}$ ). They differ from one another due to their top layers, which consist of soils with different physicalmechanical properties (tables 1,2) and different slope inclination angles as well.

The engineering geology site no. $I I_{1}$. It is built by three geotechnical layers, which are nos. 4, 5 and 6 (Fig. 3). The geotechnical layer no. 4 consists of inorganic clays of low to medium plasticity, 1.9-4.2 $\mathrm{m}$ up to $6.5-$ $8.2 \mathrm{~m}$ thick. These soils are included in the CL soil group (Samtani and Nowatzki, 2006). The geotechnical layer no. 5 represents the weathering crust of flysch rocks (FL), which are very weak rocks (Romana, 1996), 1.8-2.5 m thick. It is characterized by the same physical-mechanical properties in the whole engineering geology zone. The geotechnical layer no. 6 is comprised of flysch rocks (FL), and is mainly built of claystones-siltstones with interbedding of sandstones layers that are weak rocks (Romana, 1996). It is found in the entire engineering geology zone with the same geotechnical properties.

In the engineering geology site nos. $\mathrm{II}_{2}, \mathrm{II}_{3}, \mathrm{II}_{4}$ and $\mathrm{II}_{5}$ we analyze only the top geotechnical layers (nos. 7, 8,9 and 10), because two deeper geotechnical layers (nos. 5 and 6) are treated to engineering geology site $\mathrm{II}_{1}$.

(a) The engineering geology site no. $I_{2}$. The geotechnical layer no. 7 is composed of inorganic silts and fine sands, $1.9-3.1 \mathrm{~m}$ to $7.2 \mathrm{~m}$ thick. Ac- cording to the USCS (Samtani and Nowatzki, 2006) these soils are of ML type.

(b) The engineering geology site no. $\mathrm{II}_{3}$. The geotechnical layer no. 8 consists of inorganic clays of low to medium plasticity, $2.2-5.7 \mathrm{~m}$ thick, including to the CL soil group (Samtani and Nowatzki, 2006).

(c) The engineering geology site no. II 4 . The geotechnical layer no. 9 consists of inorganic clays of low to medium plasticity included in the CL soil group (Samtani and Nowatzki, 2006). It ranges from $3.2-5.0 \mathrm{~m}$ up to $7.5-8.7 \mathrm{~m}$ thick.

(d) The engineering geology site no. II 5 . The geotechnical layer no. 10 consists of inorganic clays of low to medium plasticity. It is included in the CL soil group (Samtani and Nowatzki, 2006) and is $2.7-5.3 \mathrm{~m}$ thick.

c. The engineering geology zone no. III, with a basement built of breccia rocks (Fig. 8). It is spread out in the northern and central part of the urban area. Referring to the criteria for engineering geology zoning mapping, this zone was distinguished at the engineering geology site $\mathrm{III}_{1}$, which represents a hill slope with an inclination angle of $14-27^{\circ}$ to the west. The basement of this site is comprised of breccia rocks 3.0-5.0 up to $12.0-15.0 \mathrm{~m}$ thick, belonging to the weak rock class (Romana, 1996). From geotechnical investigations it was observed that this zone is a stable area (Muceku, 2008).

\section{Slope stability analysis}

According to the slope stability evaluation of the urban area of Kruja, the engineering geology mapping at scale $1: 5000$ has been carried out followed by field work and laboratory tests. For the analysis of the slopes the Phase2-FEM (Rocscience, 2011) finite element software has been used; the safety factor is verified using the Slide 6.0 (Rocscience, 2010) limit equilibrium software. Uniform meshing and 6noded triangles are also used in FEM analysis. The MohrCoulomb failure criterion is chosen to model the soils and elastic-plastic material properties are used as required by shear strength reduction (SSR) analysis. The geotechnical parameters inputted in this model for each layer are the $\varphi$ internal friction angle, $\mathrm{c}$ cohesion, E elasticity module, $v$ Poisson ratio, and $\gamma$ density (tables 1 and 2). In all cases the analysis is split into two stages. In stage 1 site stress is modeled using plastic analysis, and in stage 2 the SSR analysis is performed under the effect of a specified hazard. All the above parameters have been considered in each of the following conditions: (i) dry season, (ii) heavy rains, (iii) seismic activity using PGA hazard values from the Albanian seismicity map (Kuka, 2003), and (iv) both rain and seismic activity. 
Table 3. Slope stability analysis results computed by finite element (Rocscience, 2011).

\begin{tabular}{lcccc}
\hline \multirow{2}{*}{ Site } & \multicolumn{4}{c}{ Safety factor for the condition } \\
\cline { 2 - 5 } no. & Dry & Rain & Seismic & Rain \& Seismic \\
\hline $\mathrm{I}_{1}$ & 1.24 & 0.67 & 0.67 & $0.39^{*}$ \\
$\mathrm{II}_{1}$ & 1.03 & 0.79 & 0.68 & 0.50 \\
$\mathrm{II}_{2}$ & 2.06 & 1.58 & 1.10 & 0.82 \\
$\mathrm{II}_{3}$ & 1.56 & 1.21 & 1.01 & 0.74 \\
$\mathrm{II}_{4}$ & 1.45 & 1.01 & 0.88 & 0.59 \\
$\mathrm{II}_{5}$ & 1.63 & 1.21 & 0.95 & 0.69 \\
\hline
\end{tabular}

* SF taken from limit equilibrium analysis.

The slope stability safety factor is verified with Slide 6.0 software using rigorous methods (Spencer, 1967; Morgenstern and Price, 1965). These methods divide the slope into blocks and use the equilibrium of both forces and moments for each block. The geotechnical parameters used in this model for each layer are the $\varphi$ internal friction angle, $\mathrm{c}$ cohesion and $\gamma$ density (tables 1 and 2). The equilibrium analysis in all cases was done using a polygonal search plane that corresponds to soil-rock contact in the lower part and is optimized automatically by the software at the curved parts.

In all cases (except Profile 1-1, engineering geology site no. $\mathrm{I}_{1}$ ), the results of safety factors (tables 3 and 4 ) computed from both software models are almost equal, showing only a small difference (2-5\%). FEM results on Profile 1-1 (engineering geology site no. $\mathrm{I}_{1}$ ) present the local failure and also a lack of convergence, therefore they give a nonrealistic strength reduction factor SRF (equivalent to the safety factor). From the resulting safety factor values (tables 3 and 4, engineering geology site no. $\mathrm{I}_{1}$ ) computed from equilibrium analysis the slope stability zonation maps are plotted. The results are summarized in tables 3 and 4 . The analysis has been performed using no reduction factor, so the slope may be considered safe only when $S_{\mathrm{F}}>1.3$. For the values 1.0 $\leq S_{\mathrm{F}} \leq 1.3$, the slope condition is critical and for $S_{\mathrm{F}}<1.0$ the slope is unstable. The safety factor is calculated in accordance with geotechnical and seismic conditions of the studied area. The geotechnical conditions of the urban area are related to lithological features, physical-mechanical properties of soils and rocks, as well as weather characteristics. The geotechnical investigation concluded that the upper geotechnical layers are composed of different types of soils (GP, CL and ML) and were much affected by weather conditions. These soils in arid seasons (summer-autumn) have better geotechnical properties than in wet seasons (winter-spring). From many authors (Guzzetti, et al., 2003; Vieira et al, 2010) and from our investigations carried out for the last 20 years (Muceku, 2008), the majority of slope movements occur during the wet seasons (heavy rain). For that is very important to emphasize that this area is much affected by rainfall. The mean annual rainfall is $1800-2000 \mathrm{~mm}$ per year (Themelko
Table 4. Slope stability analysis results computed by limit equilibrium (Rocscience, 2010).

\begin{tabular}{lcccc}
\hline \multirow{2}{*}{ Site } & \multicolumn{4}{c}{ Safety factor for the condition } \\
\cline { 2 - 5 } no. & Dry & Rain & Seismic & Rain \& Seismic \\
\hline $\mathrm{I}_{1}$ & 1.74 & 0.67 & 1.04 & 0.39 \\
$\mathrm{II}_{1}$ & 1.04 & 0.81 & 0.70 & 0.55 \\
$\mathrm{II}_{2}$ & 2.10 & 1.67 & 1.07 & 0.82 \\
$\mathrm{II}_{3}$ & 1.49 & 1.15 & 0.98 & 0.71 \\
$\mathrm{II}_{4}$ & 1.42 & 0.99 & 0.88 & 0.60 \\
$\mathrm{II}_{5}$ & 1.59 & 1.17 & 0.93 & 0.68 \\
\hline
\end{tabular}

and Mustaqi, 1996). In particular years, the rainfall values have been as follows: $3160.6 \mathrm{~mm}$ in $1959,3569.9 \mathrm{~mm}$ in 1960, $2518.1 \mathrm{~mm}$ in 1962 and $2288.6 \mathrm{~mm}$ in 1963 (Naçi, 1974). Also, it is important to understand that most of the rainfall occurs in the December-March period (Naçi, 1974). Furthermore, Albania represents a seismically active area in the Balkan region. It is characterized by a high seismic intensity (Papazachos et al, 2001) where many earthquakes with small magnitude $(M<4.5)$ have occurred, fewer mediumsized in magnitude (M 5.5-5.9), and rare strong earthquakes $(M>6.5)$.

That is the reason why we have taken into consideration the fact that the seismicity affects the slope stability of the studied area. The slope stability evaluation (Figs. 9, 10, 11, 12,13 and 14) concludes that the southern part of the Kruja urban area presents a real risk to the inhabitants of this area. As is shown in Fig. 15, the urban area of Kruja in the case of arid periods has a safety factor $S_{\mathrm{F}} \geq 1.45$ in the whole area, besides engineering geology site nos. $\mathrm{I}_{1}$ and $\mathrm{II}_{1}$, which are in a critical state $\left(S_{\mathrm{F}}=1.03-1.24\right)$. In saturated conditions (rainy days), our calculations point out that some areas (Fig. 16) such as engineering geology site nos. $I_{1}$ and $\mathrm{II}_{1}$ are in an unstable condition because the safety factor $S_{\mathrm{F}} \leq 0.79$ and engineering geology site nos. $\mathrm{II}_{3}, \mathrm{II}_{4}$ and $\mathrm{II}_{5}$ are in a critical state $\left(S_{F}=1.01-1.21\right)$, whereas engineering geology site no. $\mathrm{II}_{2}$ is in a stable state $\left(S_{\mathrm{F}} \geq 1.58\right)$. As mentioned above, the other factor that plays an important role in slope instability is seismic activity. Landslides triggered by earthquakes are the most unpredictable events and for this reason one of the most dangerous (Marcato et al, 2007). Therefore, a detailed slope stability analysis is completed for all hill slopes of Kruja where debris flows, earthslides and rock block rolling have been noticed. The seismic safety factor computed for engineering geology site nos. $\mathrm{I}_{1}, \mathrm{II}_{1}, \mathrm{II}_{4}$ and $\mathrm{II}_{5}$ is $S_{\mathrm{F}} \leq 0.95$ (Figs. 10 and 14), indicating that these slopes are probably unstable (Fig. 17), whereas engineering geology sites nos. $\mathrm{II}_{2}$ and $\mathrm{II}_{3}$ with $S_{\mathrm{F}}=1.01-1.10$ are in a critical state. Also, considering that the studied area has been under the effects of rainfalls and seismic activity for a long time, we have taken into account the possibility that earthquakes will occur during or within a few days after rainfalls. 
a)
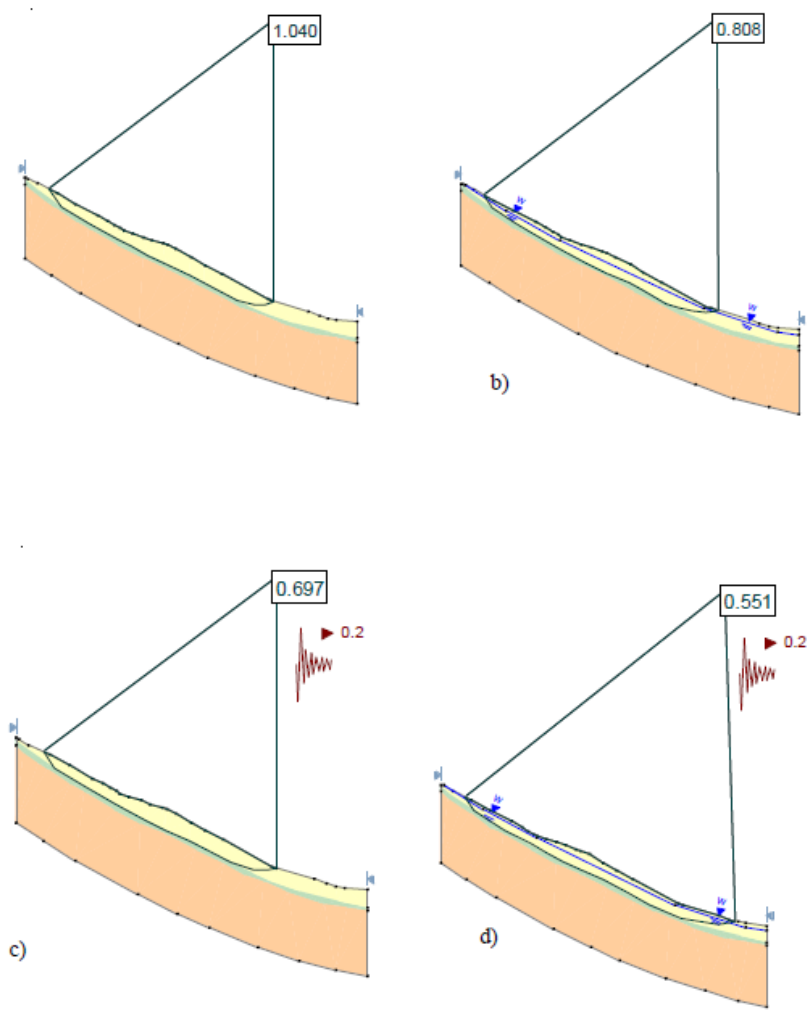

Fig. 9. Model of safety factor computed by limit equilibrium at engineering geology site no. $\mathrm{II}_{1}$ in the case of (a) arid, (b) wet, (c) PGA and (d) wet and PGA.
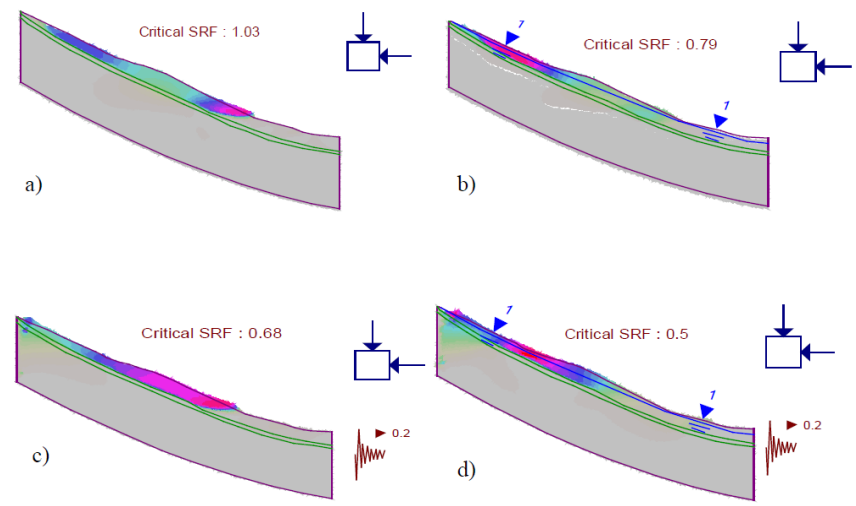

Fig. 10. Model of safety factor computed by finite element at engineering geology site no. $\mathrm{II}_{1}$ in the case of (a) arid, (b) wet, (c) PGA and (d) wet and PGA.

The computed safety factor in this case is $S_{\mathrm{F}} \leq 0.82$ (Figs. 9, $10,11,12,13$ and 14), indicating that the engineering geology sites (hill slopes) for these conditions (earthquake after heavy rainfall) are unstable and very susceptible to landslide occurrences (Fig. 18).

Finally, after field and laboratory work and FEM slope stability analysis it is concluded that:
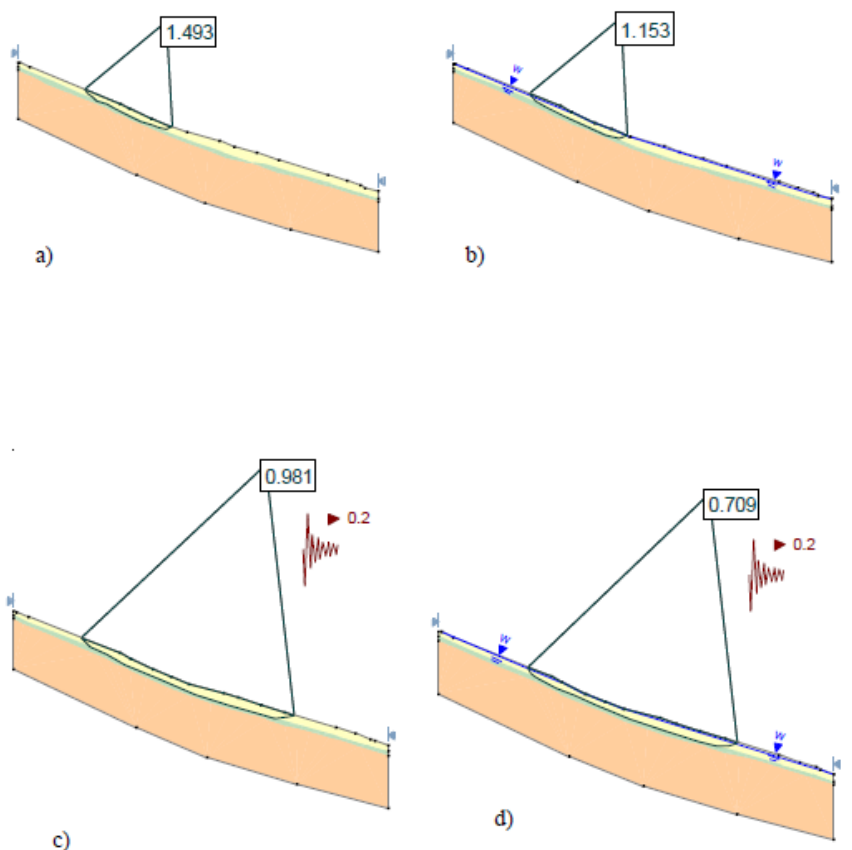

Fig. 11. Model of safety factor computed by limit equilibrium at engineering geology site no. $\mathrm{II}_{3}$ in the case of (a) arid, (b) wet, (c) PGA and (d) wet and PGA.
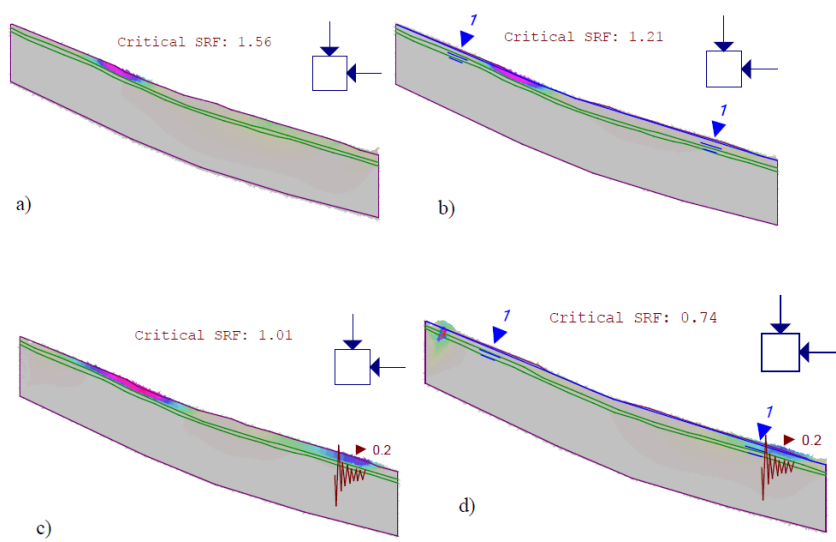

Fig. 12. Model of safety factor computed by finite element at engineering geology site no. $\mathrm{II}_{3}$ in the case of (a) arid, (b) wet, (c) PGA and (d) wet and PGA.

a. In most slope areas that are built from breccia and limestone rocks the mass movements have not occurred, therefore they are considered stable areas (Figs. 15, 16, 17 and 18).

b. The hill slopes that are located in the southern part of the urban area, covered by inorganic silts and clays with very fine sands, which are situated on flysch rocks and characterized by shallow underground water tables $(0.8-2.0 \mathrm{~m})$, are considered unstable (Figs. 16, 17 and 18). 


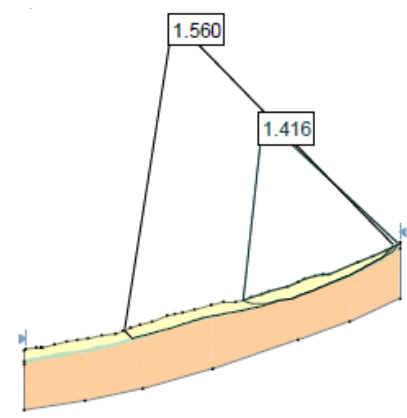

a)

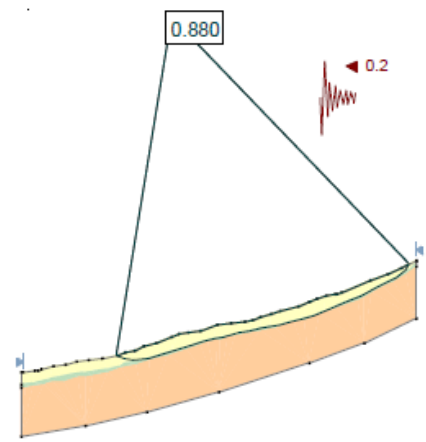

c)

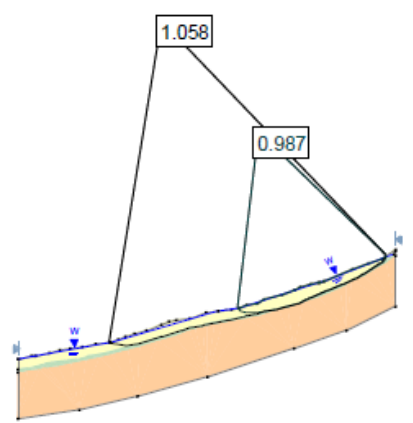

b)

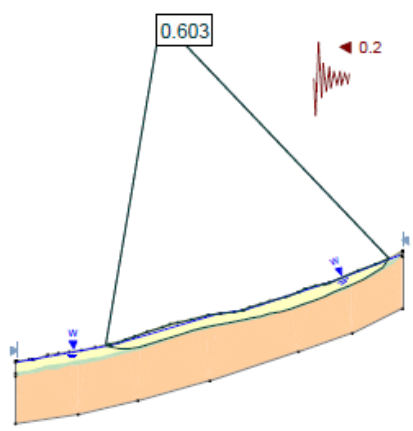

d)

Fig. 13. Model of safety factor computed by limit equilibrium at engineering geology site no. $\mathrm{II}_{4}$ in the case of (a) arid, (b) wet, (c) PGA and (d) wet and PGA.

c. Some areas of the hill slope (east of the urban area) on which are deposited diluvial soils (gravel-cobble mixture with no fines) over limestone rocks are evaluated as unstable (Figs. 16, 17 and 18).

From the analysis it is found that among factors such as lithology and geomorphology a main role in mass movement occurrences was played by underground water (after heavy rainfalls) and seismic activity.

\section{Slope stability zonation map}

The results obtained from field work, engineering geological mapping and the computation of safety factors in the urban area of Kruja have led to the compilation of the slope stability zonation maps at scale 1:5000 (Muceku, 2008). This will help the town's planners and designers for the urban area development. This compilation has been based on the evaluation of geo-factors such as lithology (soil and rock types, soil thickness), geomorphology (slope inclination), landslide occurrences, hydrogeological conditions (underground water table, rainfall, etc.), geotechnical properties of soils and rocks and slope stability safety factors.
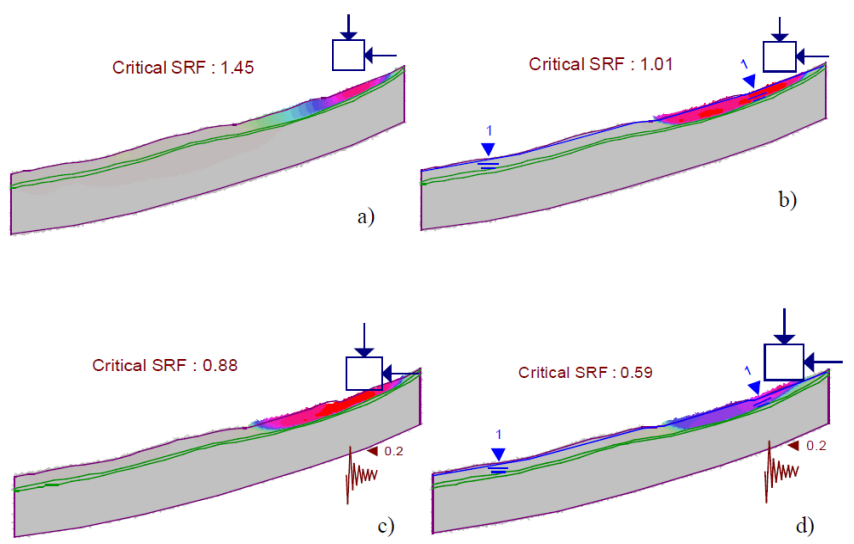

Fig. 14. Model of safety factor computed by finite element in engineering geology site no. $\mathrm{II}_{4}$ in the case of (a) arid, (b) wet, (c) PGA and (d) wet and PGA.

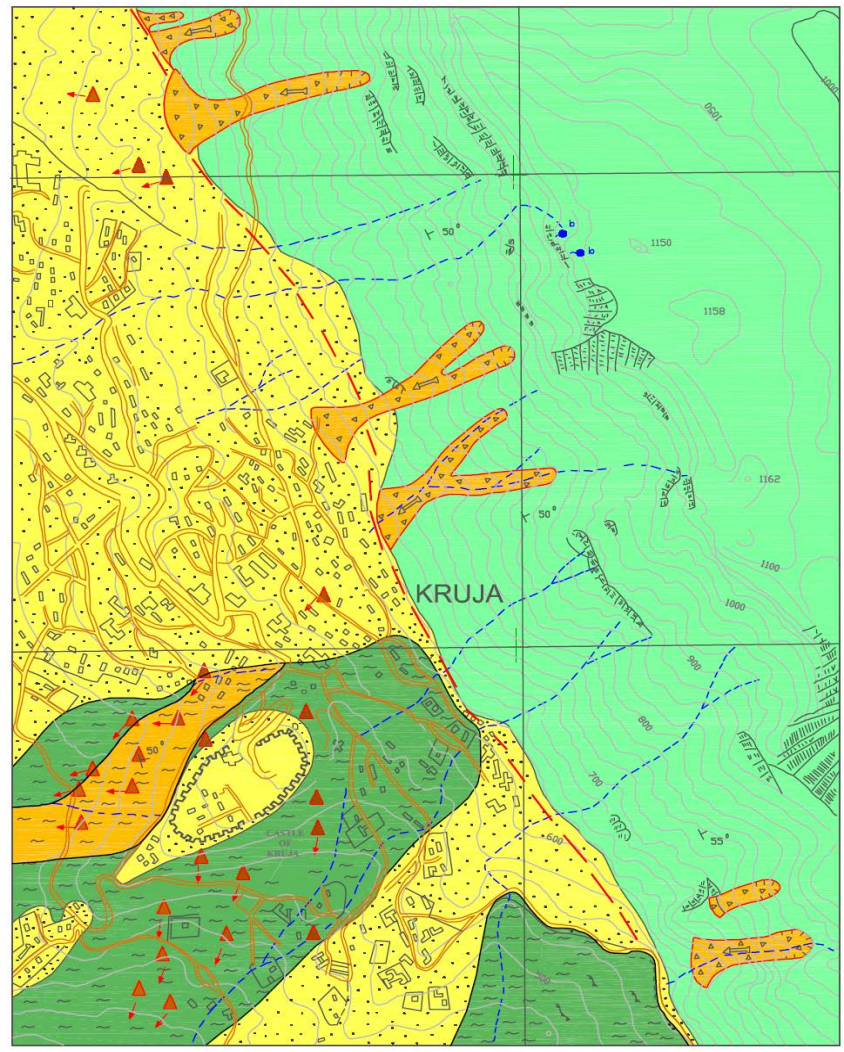
1.
2.
3
3. $\tilde{\sim} \sim \sim$.
4.

Fig. 15. Slope stability zonation map of Kruja in the case of arid periods, scale $1: 5000$. (1) engineering geology zone with basement of limestones rocks, stable, (2) engineering geology zone with basement of breccia rocks, stable, (3) engineering geology site in a critical state, (4) engineering geology site in a stable state.

The engineering geology zoning map, scale 1:5000 (Fig. 7) is divided into three engineering geology zones (Fig. 8), which are: 


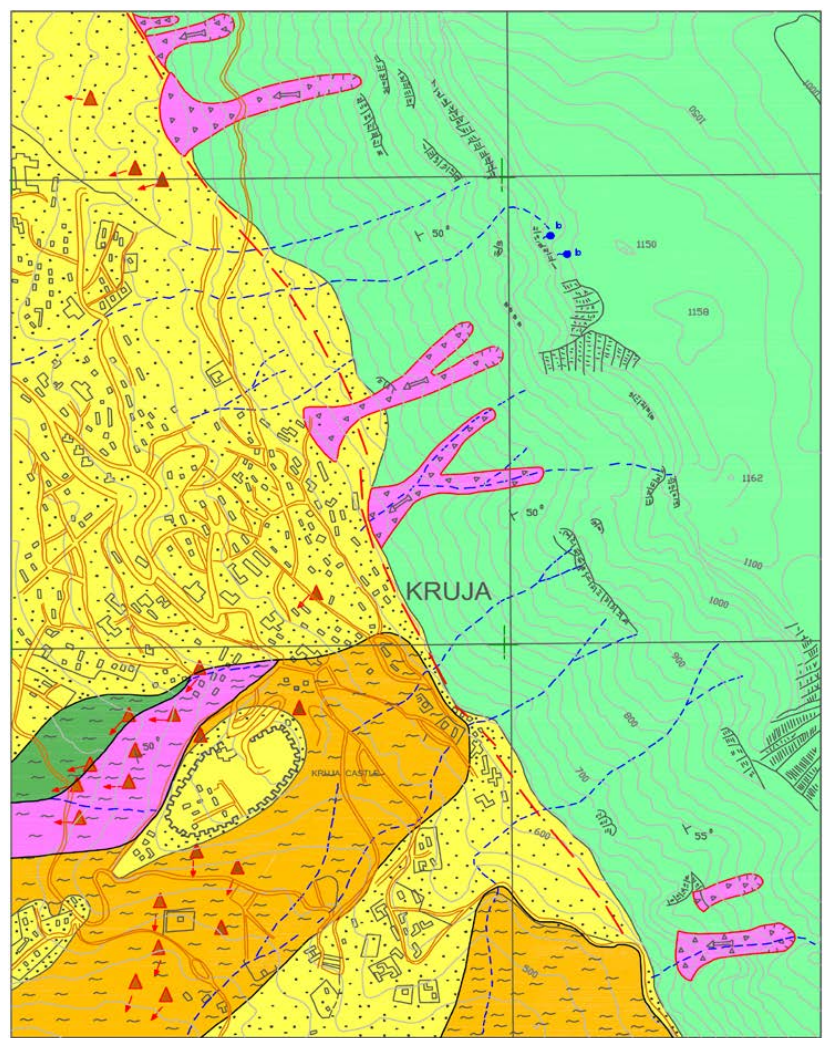
1.

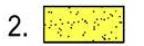
3. $\tilde{2 \sim \sim}$
4.
5. $\tilde{\sim \sim \sim}$

Fig. 16. Slope stability zonation map of Kruja in the case of rainy days, scale $1: 5000$. (1) engineering geology zone with basement of limestone rocks, stable, (2) engineering geology zone with basement of breccia rocks, stable, (3) engineering geology site in a critical state, (4) engineering geology site in a stable state, (5) engineering geology site in a unstable state.

a. The engineering geology zone (I) built of a basement of limestone rocks.

b. The engineering geology zone (II) built of a basement of flysch rocks.

c. The engineering geology zone (III) built of a basement of breccia rocks.

Based on the terrain's morphology (slope inclination angle), the soil's physical-mechanical properties and the soil's thickness, each engineering geology zone was divided into several engineering geology sites (Fig. 8), homogeneous as geotechnical characteristics. From the slope stability analysis done for each engineering geology site, the safety factor $S_{\mathrm{F}}(\mathrm{SRF})$ for different geotechnical conditions of soils and rocks was calculated for (i) dry seasons, (ii) heavy rains, (iii) seismic activity and (iv) heavy rains and seismic activity (Figs. 15, 16, 17 and 18).

In accordance with safety factor values, the engineering geology sites were classified into three categories:

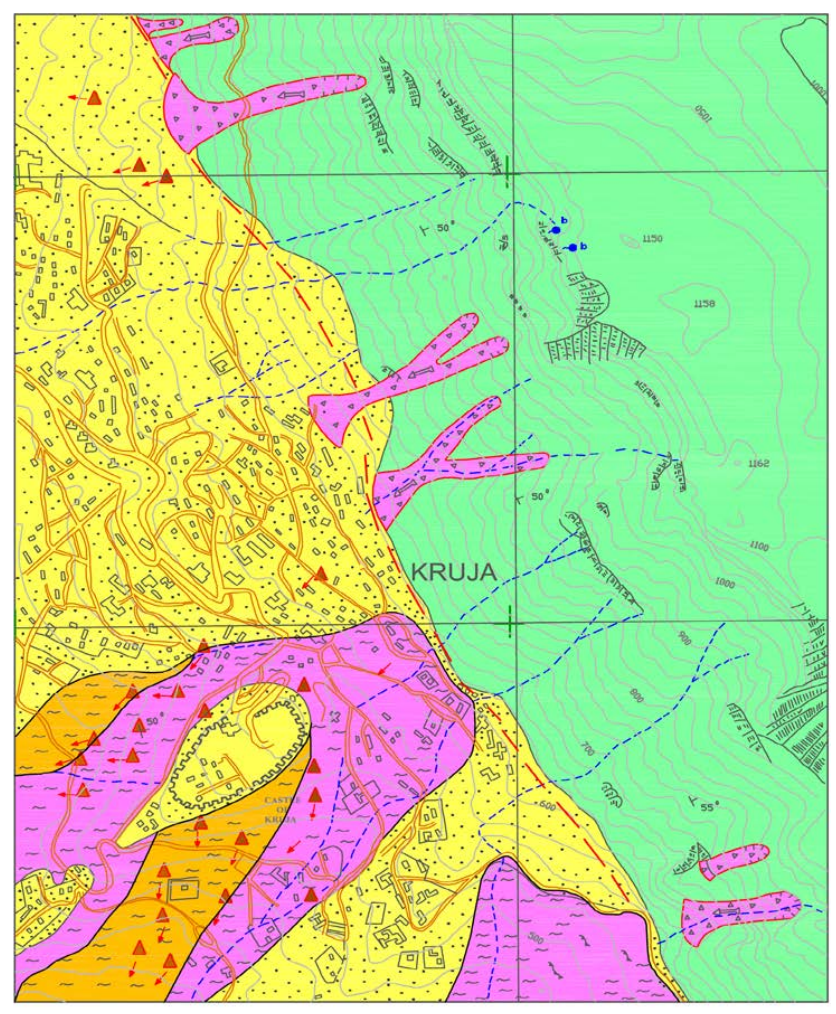

1.

2.

3.

4.

Fig. 17. Slope stability zonation map of Kruja in the case of seismic activity, scale $1: 5000$. (1) engineering geology zone with a basement of limestone rocks, stable, (2) engineering geology zone with a basement of breccia rocks, stable, (3) engineering geology site in a critical state, (4) engineering geology site in an unstable state.

1. The engineering geology sites in an unstable state $S_{\mathrm{F}}<1.0$

The slope stability evaluation concludes that a considerable area in the southern and eastern parts of Kruja, in the case of saturated conditions (rainy days) and seismic activity, is in an unstable state. This means that these slopes are characterized by a landslide occurrence, in terms of earthslide, rocks rolling and debris flow types. This category includes the engineering geology site nos. $\mathrm{I}_{1}$ and $\mathrm{II}_{1}$ (Fig. 16, saturated conditions), engineering geology site nos. $\mathrm{I}_{1}, \mathrm{II}_{1}, \mathrm{II}_{4}$ and $\mathrm{II}_{5}$ (Fig. 17, seismic activity) and engineering geology site nos. $\mathrm{I}_{1}, \mathrm{II}_{1}, \mathrm{II}_{2}, \mathrm{II}_{3}, \mathrm{II}_{4}$ and $\mathrm{II}_{5}$ (Fig. 18, saturated and seismic conditions).

2. The engineering geology site in critical state $1.0 \leq S_{\mathrm{F}} \leq 1.3$

The hill slopes in this category are in the limit equilibrium state. Here are included engineering geology sites nos. $\mathrm{I}_{1}$ and $\mathrm{II}_{1}$ (Fig. 15, arid condition), engineering geology sites nos. $\mathrm{II}_{3}, \mathrm{II}_{4}$ and $\mathrm{II}_{5}$ (Fig. 16, saturated 


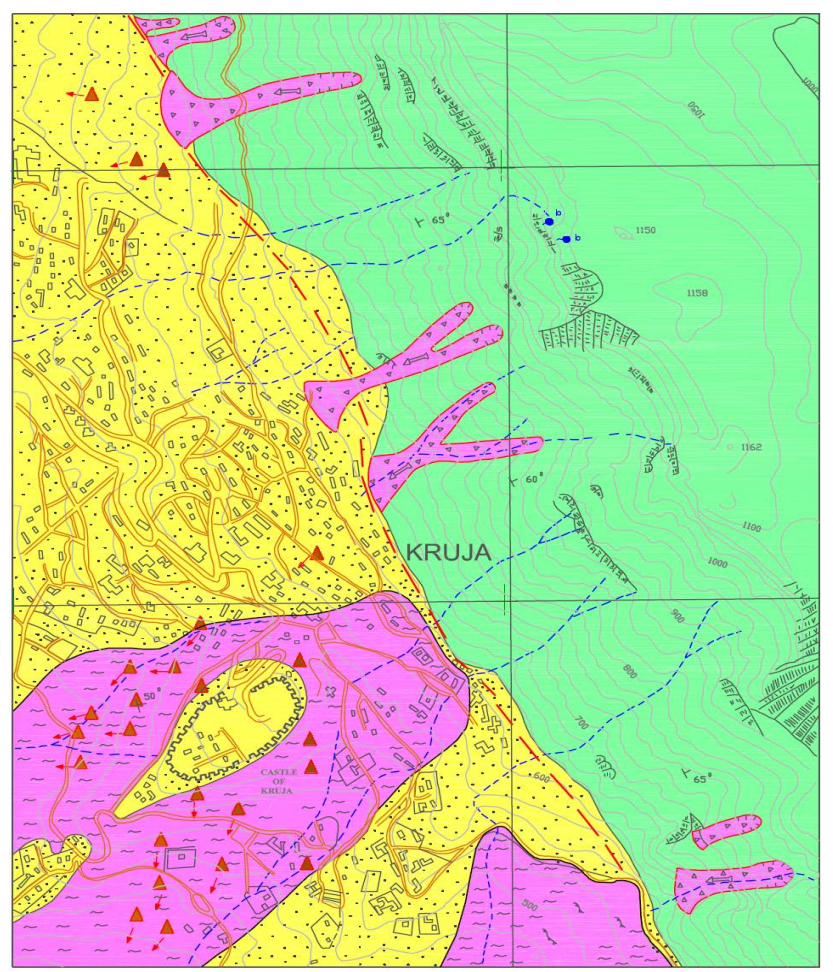

1.

2.

3.

Fig. 18. Slope stability zonation map of Kruja in the case of earthquake and rainfall occurrence at the same time, scale $1: 5000$. (1) engineering geology zone with a basement of limestone rocks, stable, (2) engineering geology zone with a basement of breccia rocks, stable, (3) engineering geology site in an unstable state.

conditions) and engineering geology sites nos. $\mathrm{II}_{2}$ and $\mathrm{II}_{3}$ (Fig. 17, seismic activity).

3. The engineering geology site in stable state $S_{\mathrm{F}}>1.3$

The hill slopes are stable from the mass movement occurrence point of view. They are shown in Fig. 15 (engineering geology site nos. $\mathrm{II}_{2}, \mathrm{II}_{3}, \mathrm{II}_{4}$ and $\mathrm{II}_{5}$ ) and Fig. 16 (engineering geology site no. $\mathrm{II}_{2}$ ). Also, this category involves the engineering geology zone nos. $\mathrm{I}_{2}$ and III built of a basement of limestone and breccia rocks (Figs. 15, 16, 17 and 18). Moreover, the slopes of the first category are included in the area with high hazards due to the fact that they will be moved down in one of the soil geotechnical conditions (rain, seismic activity and both rain and seismic activity); the second category slopes are included in the area with mediumhigh hazard because they are ready to move down, and the third category slopes are included in the stable area with no hazard.

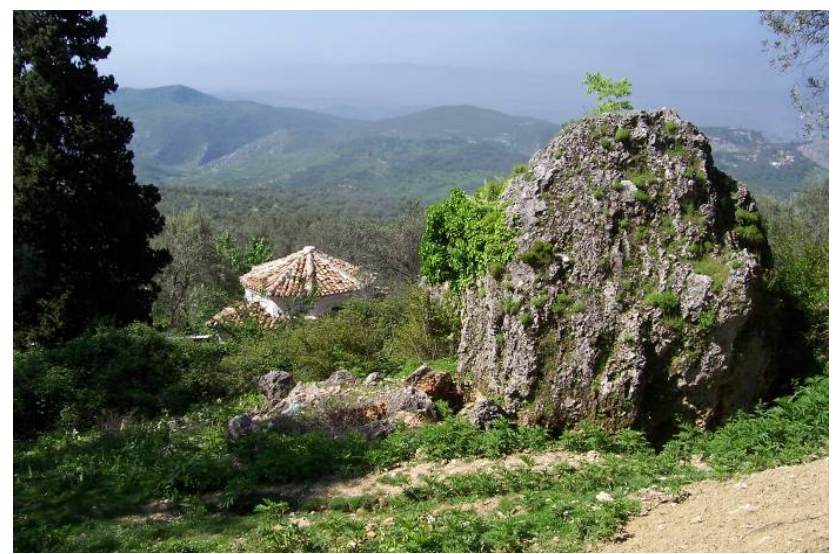

Fig. 19. A breccia block in unstable state condition.

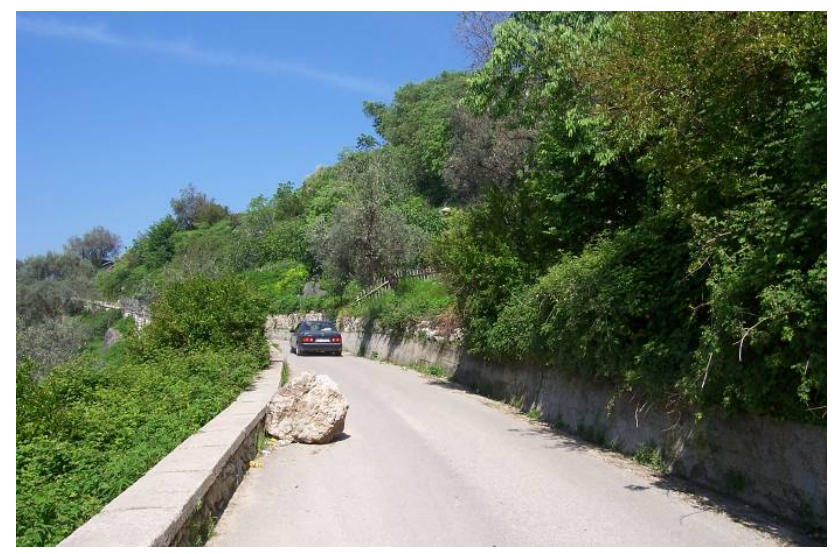

Fig. 20. A limestone block fell on the Kruja urban area during heavy rain in 2010 .

\section{Conclusions and recommendations}

The Kruja urban area is subjected to active mass movement, including earthslides, debris flows and rock rolling phenomena.

The two earthslides occurred in the central and southeastern parts of Kruja, which were, respectively: (a) $500-550 \mathrm{~m}$ long, 200-320 m wide, 4.0-8.5 m thick, and (b) $220 \mathrm{~m}$ long, $120 \mathrm{~m}$ wide and $2.8-5.5 \mathrm{~m}$ thick. The earthslide body consisted of soft silts and clays mixed with fine sands. The mass movement did not occur simultaneously in the whole of the earthslide body, but was slowly displaced to different places and at various times.

Debris flows have occurred in the eastern part of Kruja on the slopes of "Skanderbeg" mountain and with an inclination angle of $14-27^{\circ}$. They are composed of unconsolidated materials, which are represented by gravel-cobble mixtures with no content of fine materials. The dimensions of debris flows range from $120-250 \mathrm{~m}$ up to $350-400 \mathrm{~m}$ long, 50$100 \mathrm{~m}$ wide and $1.8-3.5 \mathrm{~m}$ up to $5.5-7.0 \mathrm{~m}$. The debris flows occurred in 2004 and 2010 and have been from very rapid to 
extremely rapid flows composed of saturated gravel-cobble mixtures.

These mass movements are triggered by rain and/or seismic activity. After a detailed analysis the engineering geology map is compiled, which is divided into engineering geology zones with a basement built by breccia, flysch and limestone rocks.

A finite element analysis is performed using the Phase2 (Rocscience, 2011) specialized software, and the safety factor is determined for the most typical slopes. The results are verified using the Slide (Rocscience, 2010) limit equilibrium software. The difference in the results in most cases was 2$5 \%$, proving the reliability of the analysis.

Based on safety factor " $S_{\mathrm{F}}$ " values, the engineering geology sites were classified as follows: unstable state $\left(S_{\mathrm{F}}<\right.$ 1.0 with high hazard), critical state $\left(1.0 \leq S_{\mathrm{F}} \leq 1.3\right.$ with medium-high hazard) and stable state $\left(S_{\mathrm{F}}>1.3\right.$; states with no hazard).

The conditions of the unstable areas need to be improved in order to prevent loss of life and economic or cultural heritage damages. To protect the urban area against rock block rolling, it is necessary to remove them. For protection against debris flow phenomena, engineering measures such as benches and concrete walls should be used. To protect Kasmaj, Perlataj and Berberaj squares against earthslide phenomena, engineering measures such as piles and drainage systems should be used.

Finally, mass movements such as earthslides, debris flows, rockfall and rocks rolling that are found in the urban area of Kruja represent a real risk to human life and engineering objects such as buildings, roads, etc.

Acknowledgements. The authors would like to acknowledge Albanian Geological Survey for project funding according to engineering geological zoning mapping carried out in Kruja and also the financial support for publication of this paper by Epoka University. We would like to thank the editor Thomas Glade and referees for very constructive and useful comments that helped improve this paper in present form.

Edited by: T. Glade

Reviewed by: S. Zekan and three anonymous referees

\section{References}

Cruden, D. M. and Varnes, D. J.: Landslide types and processes, in: Landslides: Investigations and Mitigation, Transportation Research Board, Special Report 247, edited by: Turner, A. K. and Schuster, R. L., 36-71, 1996.

Dahl, M.-P. J., Mortensen, L. E., Veihe, A., and Jensen, N. H.: A simple qualitative approach for mapping regional landslide susceptibility in the Faroe Islands, Nat. Hazards Earth Syst. Sci., 10, 159-170, doi:10.5194/nhess-10-159-2010, 2010.

Guzzetti, F., Reichenbach, P., and Wieczorek, G. F.: Rockfall hazard and risk assessment in the Yosemite Valley, California, USA,
Nat. Hazards Earth Syst. Sci., 3, 491-503, doi:10.5194/nhess-3491-2003, 2003.

Kuka, N., Duni, Ll., Aliaj, Sh., and Sulstarova, E.: Seismic Hazard Assessment of Albania by Spatially Smoothed Seismicity Approach International, Conference on Earthquake Engineering, Ohrid, FYROM, 78-85, 2003.

Marcato, G., Fujisawa, K., Mantovani, M., Pasuto, A., Silvano, S., Tagliavini, F., and Zabuski, L.: Evaluation of seismic effects on the landslide deposits of Monte Salta (Eastern Italian Alps) using distinct element method, Nat. Hazards Earth Syst. Sci., 7, 695701, doi:10.5194/nhess-7-695-2007, 2007.

Meço, S. and Aliaj, Sh.: Neotectonics and seismicity in Albania. Geology of Albania, Gebrüder Borntraeger, Berlin, 155-178, 2000.

Morgenstern, N. R. and Price V. E.: The analysis of the stability of general slip surfaces. Géotechnique, 15, 79-93, 1965.

Muceku, Y.: Engineering geological zoning mapping for urban development of Kruja town, scale $1: 5000$, Center of Civil Geology, Tirana, Albania, 1, 47-105, 2008.

Muceku, Y.: The mass movement response of tectonics phenomena in urban areas, Albania, 17th International Conference on Soils Mechanics and geotechnical Engineering, Alexandria, Egypt, vol. 2, 1726-1730, 2009

Naçi, R.: Rainfalls in Albania, Albanian clime's publication, Albanian Sciences Academy, vol. 1, 60-61, 1974.

Papazachos, B. C.: Savvaidis, A. S., Papazachos, C. B., Papaioannou, Ch. A., Kiratzi, A. A., Muco, B., Kociu, S., and Sulstarova, E.: Atlas of Isoseismal Maps for Shallow Earthquakes in Albania and Surrounding Area (1851-1990), Aristotle University of Thessaloniki, Geophysical Laboratory, Publication Nr. 10, 2-58, 2001.

Rocscience Inc.: Slide Version 6.0-2-D Limit Equilibrium Slope Stability Analysis, www.rocscience.com, Toronto, Ontario, Canada, 2010.

Rocscience Inc.: Phase 2 Version 8.0-2-D FEM Geotechnical Analysis, www.rocscience.com, Toronto, Ontario, Canada, 2011.

Romana, M. R.: A Geomechanical Classification for Slopes: Slope Mass Rating, Pergamon Press Ltd, Headington Hill Hall, Oxford, OX3 0BW, England, vol. 3, 15-16, 1996.

Samtani, N. C. and Nowatzki, E. A.: Unified Soil Classification System, (ASTM D 2487), Soils and Foundations, National Highway Institute, Reference Manual-vol. I, 3-25, 2006.

Spencer, E.: A method of analysis of the stability of embankments assuming parallel interslice forces, Géotechnique, 17, 11-26, 1967.

Themelko, B. and Mustaqi, V.: Rainfalls in Albania. Water as a national asset, the research and management of water resources of Albania. National Conference, Tirana, Albania, 1-2 October 1996, 129-133, 1996.

Vieira, B. C., Fernandes, N. F., and Filho, O. A.: Shallow landslide prediction in the Serra do Mar, São Paulo, Brazil, Nat. Hazards Earth Syst. Sci., 10, 1829-1837, doi:10.5194/nhess-101829-2010, 2010.

Xhomo, A., Kodra, A., Dimo, Ll., Xhafa Z., Nazaj, Sh., Nakuçi, V., Yzeiraj, D., Shallo, M., Vranaj, A., and Melo, V.: Geological map of Albania, Geological Survey of Albania, 1, 117-121, 2002. 